Research Article

\title{
Comparison of awareness, attitude and use of non-prescription drugs among medical and non-medical undergraduates: a questionnaire based study
}

\author{
Deepika Tikoo*, Meenakshi Gupta, Geeta Sharma
}

Department of Pharmacology, Sri Guru Ram Das Institute of Medical Sciences \&Research, Vallah, Amritsar, Punjab, India

Received: 23 January 2016

Accepted: 09 February 2016

*Correspondence to:

Dr. Deepika Tikoo,

Email: dtikoo@gmail.com

Copyright: () the author(s), publisher and licensee Medip Academy. This is an openaccess article distributed under the terms of the Creative Commons Attribution NonCommercial License, which permits unrestricted noncommercial use, distribution, and reproduction in any medium, provided the original work is properly cited.

\begin{abstract}
Background: The use of non-prescription drugs for self-treatment of common ailments is becoming increasingly popular in our society. Trends in the use of non-prescription drugs is expected to vary among medical students and the general population, as medical students have more knowledge about drugs and an easy access to them. In the present study we have done a comparison regarding the awareness, attitudes and use of over the counter drugs among medical and non-medical undergraduates to evaluate these parameters.

Methods: A total of 139 third year medical students and 101 non-medical students were included in our study. An anonymous, pre-validated questionnaires containing questions about their knowledge, attitude and perception of non-prescription drugs were filled by them. The data collected was compiled and analyzed by frequency analysis and percentages.

Results: Majority of the medical (99.3\%) and non-medical students $(95.1 \%)$ had purchased non-prescription drugs from either a local pharmacy $(83.4 \%$, $61.4 \%$ medical \& non-medical students respectively) or from seniors, friends \& family members ( $18 \%$ medical \& $18.8 \%$ non-medical students). The commonest indication for self-medication in both the groups was cough $\&$ cold (80.6\% medical \& $55.4 \%$ non-medical group) followed by fever in medical students $(77.7 \%)$ and headache in non-medical students $(39.6 \%)$. Antipyretics $(66.9 \%)$ in medical students and analgesics $(39.6 \%)$ in non-medical students were the commonest drug groups used. The medical students preferred to buy brand drugs (47.5\%) as compared to generic drugs $(26.6 \%)$ while the nonmedical students had no preference $(48.5 \%)$ about the form of drugs. About $57.6 \%$ medical and $61.4 \%$ non-medical students never experienced any side effect with over the counter drugs. Many medical $(57.5 \%)$ and non-medical $(40.6 \%)$ students supported the sale of non-prescription drugs for minor ailments.

Conclusions: There is an increasing trend of self-medication among the youth today. Medical students have a better access to such drugs hence are expected to self-medicate more. But the easy availability about drug information on the internet and their unrestricted supply in the pharmacies are escalating the practice of self-medication among the general population too. It therefore becomes imperative to create awareness against the injudicious use of over the counter drugs without a valid medical prescription to promote rational drug use.
\end{abstract}

Keywords: Non-prescription drugs, Self-medication, Medical students, Nonmedical students

\section{INTRODUCTION}

A drug is defined by World Health Organization (WHO) as "any substance or product that is used or is intended to be used to modify or explore physiological systems or pathological states for the benefit of the recipient". Pharmacotherapy if practiced in an appropriate and rational manner can benefit the populations with less 
chances of developing adverse drug reactions (ADR). The drugs are dispensed to the patient either with mandatory prescription letter from a registered practitioner (prescription drugs) or are readily sold by the pharmacist to the general population without a physician's prescription (non-prescription drugs). Nonprescription drugs are also known as over the counter (OTC) drugs and in India, all the drugs not included in the list of prescription drugs are considered OTC drugs. Under the Drugs and Cosmetics Rules, 1945, the prescription drugs fall under two categories: Schedule $\mathrm{H}$ and Schedule X. Drugs which fall under Schedule G require a label that is mandatory which says "Caution: It is dangerous to take this preparation except under medical supervision". 2,3

Self-medication is the use of drugs (allopathic, ayurvedic, homeopathic and others) for self-care and treatment of self-recognized illness without proper professional advice. $^{4,5}$

Self-medication is becoming increasingly popular among the general population for treatment of minor problems as it is economical, time saving and not dependent on physician's availability. ${ }^{4-7}$ The WHO supports the fact that if responsible and controlled Self-medication is practiced, it can cause prompt and effective relief of common illness which can decrease the burden on health care services which are deficient in most of developing countries while hugely expensive in developed countries. This use of non-prescription drugs must however be supported by an appropriate health information. ${ }^{5,7}$

The medical students, who are the future health care providers are an integral part of the society and are showing an increased trend towards practice of Selfmedication as they have resources for knowledge about the drugs and disease and an easy access to the medications. The non-medical students on the other hand consume non-prescription drugs under the influence of family, friends, internet, advertisements and most important easy availability of these drugs from the drug store. In this scenario, the present study was undertaken to compare the knowledge, attitude and practices towards the use of non-prescription drugs among medical and non-medical undergraduates and see whether different educational backgrounds leads to differences in trends of self-medication.

\section{METHODS}

After getting the approval from the institutional ethics Committee, a total of 139 third year medical students (only allopathic students who had knowledge of pharmacology) and 101 non-medical students were included in our study. They were first briefed about the purpose of the study and after that informed consent was obtained from them. The data was collected using an anonymous, pre-validated, semi structured questionnaire which included both closed ended and open ended questions on their knowledge, attitude and perception of non-prescription drugs, which was filled by the students. The data collected was compiled in a pre-structured format and analysed by frequency analysis and percentages.

\section{RESULTS}

A total of 139 third year medical students including 51 (36.7\%) males; $88(63.3 \%)$ females and 101 non-medical students including $44(43.6 \%)$ males and $57(56.4 \%)$ females participated in the present study of selfmedication. All were in the age group of 18-25 years.

\section{Knowledge regarding self-medication}

The data revealed that majority of the medical students $(87.8 \%)$ knew that non-prescription drugs were also known as over the counter (OTC) drugs while only $22.8 \%$ non-medical students knew about it. About $13.9 \%$ non-medical students mentioned that they did not know what non-prescription drugs was (Table 1). The important sources of knowledge about non-prescription drugs in both the groups were previous doctor prescriptions available (33.1\% medical; $31.7 \%$ non-medical) followed by information from senior students and family members (35.9\% medical \& $21.8 \%$ non-medical), pharmacology books ( $41.7 \%$ medical; $2.9 \%$ non-medical) etc. (Figure 1). About $72.7 \%$ of students from medical group and $33.7 \%$ in non-medical group were aware of the importance of completing the full course of medication.

The knowledge about drug interactions among different medicines was known to $93.5 \%$ medical students as compared to $31.7 \%$ non-medical students which is a marked difference. Regarding awareness about the adverse drug reactions (ADRs) of OTC drugs, $27.7 \%$ non-medical students felt that these drugs were safe to use as compared to $8.6 \%$ medical students. About $64.7 \%$ medical students and $34.6 \%$ non-medical students answered that these medicines had minor ADRs which were tolerable. When asked about the safety of the nonprescription drugs in pregnant women, children and elderly, $41 \%$ medical students felt that they should never be used in these populations groups, while $50.4 \%$ said that they can be used under doctor's supervision. In the non-medical group, $54.5 \%$ felt that OTC drugs should never be used in these populations while $22.8 \%$ responded that they could be used under doctor's supervision.

\section{Attitude regarding self-medication}

Our data (Table 2) reflects the attitudes of medical and non-medical students towards procurement of OTC drugs. About $47.5 \%$ medical students and $40.6 \%$ nonmedical students preferred to buy brand drugs as compared to $26.6 \%$ medical and $9.9 \%$ non-medical students who bought generic drugs. Others $(25.9 \%$ medical \& $48.5 \%$ non-medical students) had no 
preference for the form of non-prescription drugs. For $46.8 \%$ medical respondents, buying the non-prescription drugs in proper dosage was a habit while this was the case with $32.7 \%$ non-medical students. Random purchase of such drugs without proper dosage was also a practice with $20.9 \%$ medical and $33.7 \%$ non-medical students. Side effects or ADRs with these drugs was observed sometimes among $31.6 \%$ medical and $22.8 \%$ nonmedical students while it was never experienced by $57.6 \%$ and $61.4 \%$ medical \& non-medical groups respectively. In our study, majority of the students (75.5\% medical and $63.4 \%$ non-medical) preferred prescription drugs over non-prescription drugs. Those who preferred non-prescription drugs did so for minor diseases like fever, cough $\&$ cold, headache etc, due to prior experience with the ailment $\&$ its medicine and lack of time to visit a doctor. Many respondents $(63.3 \%$ medical \& $37.6 \%$ non-medical) felt that non-prescription drugs should come with a drug information leaflet and they also felt ( $50.3 \%$ medical \& $38.6 \%$ non-medical) that banning of such drugs in India is not required. Many of the students, $57.5 \%$ medical \& $40.6 \%$ non-medical responded that the sale of these drugs is fine for minor ailments and these could be sold if a doctor is unavailable but $28.1 \%$ medical \& $39.6 \%$ non-medical students felt otherwise as they said that a medical consultation is always important and sale of such OTC drugs should not be encouraged.

Table 1: Knowledge regarding self-medication.

\begin{tabular}{|c|c|c|}
\hline \multirow[b]{2}{*}{ Questions } & \multicolumn{2}{|l|}{ Response } \\
\hline & $\begin{array}{l}\text { Medical students } \\
\text { number }(\%)\end{array}$ & $\begin{array}{l}\text { Non-medical students } \\
\text { number }(\%)\end{array}$ \\
\hline \multicolumn{3}{|l|}{ Do you know what non-prescription drugs are? } \\
\hline Over the counter (OTC) drugs & $122(87.8)$ & $23(22.8)$ \\
\hline Drugs dispensed by the chemist on physician's order & Nil & $18(17.8)$ \\
\hline Drugs dispended by anyone & $17(12.2)$ & $46(45.5)$ \\
\hline Don't know & Nil & $14(13.9)$ \\
\hline \multicolumn{3}{|l|}{$\begin{array}{l}\text { Are you aware about the importance of completing the course } \\
\text { of medication? }\end{array}$} \\
\hline Yes, I always buy medicine for full course & $101(72.7)$ & $34(33.7)$ \\
\hline No, just buy randomly & $5(3.6)$ & $24(23.8)$ \\
\hline $\begin{array}{l}\text { Completing the course of drugs for minor ailments is not } \\
\text { important }\end{array}$ & $13(9.3)$ & $14(13.9)$ \\
\hline Stop medication as soon as symptoms improve & $20(14.4)$ & $26(25.7)$ \\
\hline No response & Nil & $3(2.9)$ \\
\hline \multicolumn{3}{|l|}{$\begin{array}{l}\text { Are you aware of drug interactions among various } \\
\text { medications? }\end{array}$} \\
\hline No & $5(3.6)$ & $41(40.6)$ \\
\hline Yes & $130(93.5)$ & $32(31.7)$ \\
\hline Just heard about it but no sound knowledge of its importance & $4(2.9)$ & $28(27.7)$ \\
\hline \multicolumn{3}{|l|}{$\begin{array}{l}\text { Do non-prescription drugs have side effects/adverse drug } \\
\text { reactions (ADRs)? }\end{array}$} \\
\hline No, they are safe to use & $12(8.6)$ & $28(27.7)$ \\
\hline Yes, they are not safe to use & $37(26.6)$ & $37(36.6)$ \\
\hline They have minor ADRs which are tolerable & $90(64.7)$ & $35(34.6)$ \\
\hline \multicolumn{3}{|l|}{$\begin{array}{l}\text { Can non-prescription drugs be used safely in pregnant } \\
\text { women, children and elderly patients? }\end{array}$} \\
\hline No Never & $57(41.0)$ & $55(54.5)$ \\
\hline Yes Always & $4(2.9)$ & $13(12.9)$ \\
\hline Under doctor's supervision & $70(50.4)$ & $23(22.8)$ \\
\hline Can use sometimes for minor ailments & $8(5.7)$ & $9(8.9)$ \\
\hline No response & Nil & $1(0.9)$ \\
\hline \multicolumn{3}{|l|}{ Antibiotics are used to treat: } \\
\hline Bacterial infections & $104(74.8)$ & $15(14.9)$ \\
\hline Viral infections & $5(3.6)$ & $21(20.8)$ \\
\hline Fungal infections & $5(3.6)$ & $6(5.9)$ \\
\hline Both bacterial and viral infections & $24(17.3)$ & $30(29.7)$ \\
\hline I don't know & Nil & $29(28.7)$ \\
\hline No response & $1(0.7)$ & Nil \\
\hline
\end{tabular}


Table 2: Attitude regarding self-medication.

\begin{tabular}{|c|c|c|}
\hline \multirow[b]{2}{*}{ Questions } & \multicolumn{2}{|l|}{ Response $(\%)$} \\
\hline & Medical students number & $\begin{array}{l}\text { Non-medical students } \\
\text { number }\end{array}$ \\
\hline \multicolumn{3}{|l|}{ Which form of non-prescription drugs do you prefer? } \\
\hline Generic drugs & $37(26.6)$ & $10(9.9)$ \\
\hline Brand drugs & $66(47.5)$ & $41(40.6)$ \\
\hline No preference & $36(25.9)$ & $49(48.5)$ \\
\hline No response & Nil & $1(0.9)$ \\
\hline \multicolumn{3}{|l|}{$\begin{array}{l}\text { Do you procure non-prescription drugs in proper dosage while } \\
\text { purchasing? }\end{array}$} \\
\hline Yes always & $65(46.8)$ & $33(32.7)$ \\
\hline No just buy randomly & $29(20.9)$ & $34(33.7)$ \\
\hline Consult books for dose and then buy & $11(7.9)$ & $3(2.9)$ \\
\hline Consult friend/relative on phone and then buy & $33(23.7)$ & $15(14.8)$ \\
\hline Refer to internet and then buy & $1(0.7)$ & $11(10.9)$ \\
\hline No response & Nil & $5(4.9)$ \\
\hline \multicolumn{3}{|l|}{$\begin{array}{l}\text { Have you experienced any side effect with non-prescription } \\
\text { drugs? }\end{array}$} \\
\hline Never & $80(57.6)$ & $62(61.4)$ \\
\hline Sometimes & $44(31.6)$ & $23(22.8)$ \\
\hline Do not know if it was related to self-medication & $15(10.8)$ & $10(9.9)$ \\
\hline No response & Nil & $6(5.9)$ \\
\hline \multicolumn{3}{|l|}{$\begin{array}{l}\text { Do you prefer non-prescription drugs over prescription } \\
\text { drugs? }\end{array}$} \\
\hline Yes & $10(7.2)$ & $12(11.9)$ \\
\hline No & $105(75.5)$ & $64(63.4)$ \\
\hline No opinion & $24(17.3)$ & $23(22.8)$ \\
\hline \multicolumn{3}{|l|}{$\begin{array}{l}\text { If yes, then why do you prefer to buy non-prescription drugs } \\
\text { rather than going to a physician? }\end{array}$} \\
\hline Prior experience with the ailment and its medicine & $5(3.6)$ & $1(0.9)$ \\
\hline For minor diseases & $5(3.6)$ & $9(8.9)$ \\
\hline Lack of time to visit a physician & Nil & $2(1.9)$ \\
\hline It is convenient and easy to buy & Nil & Nil \\
\hline Do not have to pay physician's fee & Nil & Nil \\
\hline \multicolumn{3}{|l|}{$\begin{array}{l}\text { If you have never purchased non-prescription drugs, what is } \\
\text { the reason? }\end{array}$} \\
\hline Fear of incorrect medication intake & Nil & Nil \\
\hline Fear of adverse effects of medicines & Nil & Nil \\
\hline Do not take medicine for minor illness & $1(0.7)$ & $3(2.9)$ \\
\hline Always prefer to consult a registered doctor first & Nil & $2(1.9)$ \\
\hline I have purchased non-prescription drugs & $121(87.1)$ & $92(91.1)$ \\
\hline No response & $17(12.2)$ & $4(3.9)$ \\
\hline \multicolumn{3}{|l|}{$\begin{array}{l}\text { Do you feel all non-prescription drugs should come with drug } \\
\text { information leaflets? }\end{array}$} \\
\hline Strongly agree & $88(63.3)$ & $38(37.6)$ \\
\hline Somewhat agree & $32(23.0)$ & $18(17.8)$ \\
\hline Strongly Disagree & $7(5.0)$ & $7(6.9)$ \\
\hline Disagree & $2(1.4)$ & $5(4.9)$ \\
\hline No opinion & $10(7.2)$ & $30(29.7)$ \\
\hline No response & Nil & $3(2.9)$ \\
\hline \multicolumn{3}{|l|}{$\begin{array}{l}\text { Do you think non-prescription drugs need to be banned in } \\
\text { India? }\end{array}$} \\
\hline Yes & $34(24.5)$ & $22(21.8)$ \\
\hline No & $70(50.3)$ & $39(38.6)$ \\
\hline No opinion & $35(25.2)$ & $40(39.6)$ \\
\hline \multicolumn{3}{|l|}{ Do you support the sale of non-prescription drugs? } \\
\hline Yes for minor ailments & $80(57.5)$ & $41(40.6)$ \\
\hline No, a medical consultation is always better before buying drugs & $39(28.1)$ & $40(39.6)$ \\
\hline If my friends/ family are taking it, it is safe for me too & Nil & $8(7.9)$ \\
\hline Can be sold only in emergency if the doctor is unavailable & $20(14.4)$ & $12(11.9)$ \\
\hline
\end{tabular}


Table 3: Practices towards self-medication.

\begin{tabular}{|c|c|c|}
\hline \multirow[b]{2}{*}{ Questions } & \multicolumn{2}{|l|}{ Response } \\
\hline & $\begin{array}{l}\text { Medical students } \\
\text { number }(\%)\end{array}$ & $\begin{array}{l}\text { Non-medical students } \\
\text { number }(\%)\end{array}$ \\
\hline \multicolumn{3}{|l|}{ Have you ever purchased non-prescription drugs? } \\
\hline Never & $1(0.7)$ & $5(4.9)$ \\
\hline Yes, many times & $93(66.9)$ & $31(30.7)$ \\
\hline Yes, but only in emergency when doctor is unavailable & $45(32.4)$ & $65(64.4)$ \\
\hline \multicolumn{3}{|l|}{$\begin{array}{l}\text { If the answer to the above question is yes, then from where did } \\
\text { you procure them? }\end{array}$} \\
\hline Pharmacy & $116(83.4)$ & $62(61.4)$ \\
\hline Online & $3(2.1)$ & $7(6.9)$ \\
\hline From a senior/friend/relative & $25(18.0)$ & $19(18.8)$ \\
\hline Drugs left over from past prescriptions & $14(10.1)$ & $10(9.9)$ \\
\hline Other sources & Nil & Nil \\
\hline \multicolumn{3}{|l|}{ How frequently do you purchase non-prescription drugs? } \\
\hline Once every week & Nil & Nil \\
\hline Once every two weeks & $8(5.8)$ & $7(6.9)$ \\
\hline Once every three weeks & $8(5.8)$ & $5(4.9)$ \\
\hline Once every month & $50(35.9)$ & $27(26.7)$ \\
\hline Once in six months & $46(33.1)$ & $36(35.6)$ \\
\hline Once every year & $13(9.3)$ & $20(19.8)$ \\
\hline As and when required & $10(7.2)$ & $1(0.9)$ \\
\hline No response & $4(2.9)$ & $5(4.9)$ \\
\hline \multicolumn{3}{|l|}{$\begin{array}{l}\text { Do you take non-prescription drugs with your family member's } \\
\text { consent? }\end{array}$} \\
\hline No, I have more medical knowledge than them & $17(12.2)$ & $13(12.9)$ \\
\hline Sometimes I tell them & $26(18.7)$ & $20(19.8)$ \\
\hline Yes, I always take their advice & $86(61.9)$ & $50(49.5)$ \\
\hline If my illness does not improve, then I tell them & $10(7.2)$ & $13(12.8)$ \\
\hline No response & Nil & $5(4.9)$ \\
\hline \multicolumn{3}{|l|}{$\begin{array}{l}\text { While procuring non-prescription drugs, do you ever check the } \\
\text { expiry date of the medicine? }\end{array}$} \\
\hline Yes always & $129(92.8)$ & $80(79.2)$ \\
\hline No never & Nil & $8(7.9)$ \\
\hline Sometimes & $10(7.2)$ & $8(7.9)$ \\
\hline I don't know what is expiry date & Nil & Nil \\
\hline No response & Nil & $5(4.9)$ \\
\hline \multicolumn{3}{|l|}{$\begin{array}{l}\text { Do you look at the brand of the drug and the manufacturing } \\
\text { company while buying non-prescription drugs? }\end{array}$} \\
\hline No, I always buy generic drugs & $40(28.8)$ & $13(12.9)$ \\
\hline Yes, I always buy foreign company drugs & $45(32.4)$ & $30(29.7)$ \\
\hline Yes, I buy the cheaper brand drugs & $14(10.1)$ & $12(11.9)$ \\
\hline No, I take whatever the pharmacist gives me & $38(27.3)$ & $41(40.6)$ \\
\hline No response & $2(1.4)$ & $5(4.9)$ \\
\hline \multicolumn{3}{|l|}{ Do you advice use of non-prescription drugs to others? } \\
\hline Yes to my friends/ family & $52(37.4)$ & $24(23.8)$ \\
\hline Yes if a patient consults me & $27(19.4)$ & $13(12.9)$ \\
\hline No, I am not confident about advising them to anyone & $60(43.2)$ & $62(61.3)$ \\
\hline No response & Nil & $2(1.9)$ \\
\hline \multicolumn{3}{|l|}{$\begin{array}{l}\text { Do you take ayurvedic, homeopathic medicines along with } \\
\text { allopathic medicines? }\end{array}$} \\
\hline Yes & $19(13.7)$ & $17(16.8)$ \\
\hline Never & $80(57.6)$ & $33(32.7)$ \\
\hline Sometimes & $38(27.3)$ & $39(38.6)$ \\
\hline Have no knowledge about ayurvedic/homeopathic medicines & $2(1.4)$ & $7(6.9)$ \\
\hline No response & $\mathrm{Nil}$ & $5(4.9)$ \\
\hline
\end{tabular}




\section{Practices towards self-medication}

The present study revealed that majority of the students in both the groups (medical $99.3 \%$ \& non-medical 95.1\%) had purchased non-prescription drugs as has been shown in Table 3. The frequency of purchase of these drugs was usually once a month $(35.9 \%$ medical, $26.7 \%$ non-medical) or once in six months $(33.1 \%$ medical \& $35.6 \%$ non-medical) in both the groups. Most of them (83.4\% medical \& $61.4 \%$ non-medical students) procured them from a local pharmacy. They $(61.9 \%$ medical \& $49.5 \%$ non-medical) took the advice of a family member before buying these drugs. It was good to know that most of the students checked for the expiry date of OTC drugs (92.8\% medical \& $79.2 \%$ non-medical students).The common ailments for which OTC drugs were procured were fever, cold \& cough, headache etc. (Figure 2) and the common non-prescription drugs bought were analgesics \& antipyretics like paracetamol, aspirin, diclofenac etc; antacids (omeprazole, ranitidine); multivitamins like becosule \& supradyn etc. (Figure 3). About $37.4 \%$ medical and $23.8 \%$ non-medical students advised the use of non-prescription drugs to their family or friends while $43.2 \%$ medical \& $61.3 \%$ non-medical students were not confident about prescribing such drugs to anyone. The consumption of ayurvedic or homeopathic medicines along with allopathic drugs was seen in $41 \%$ medical and $55.4 \%$ non-medical students.

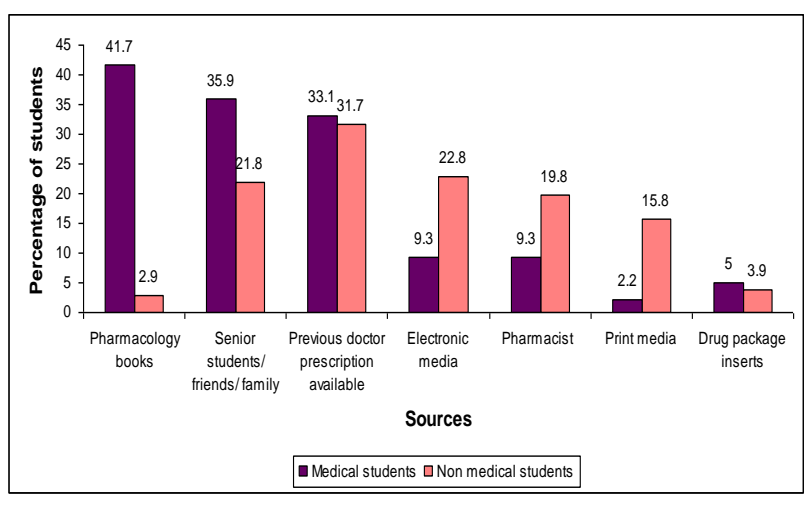

Figure 1: Sources of information about nonprescription drugs.



Figure 2: Common ailments for self-medication.

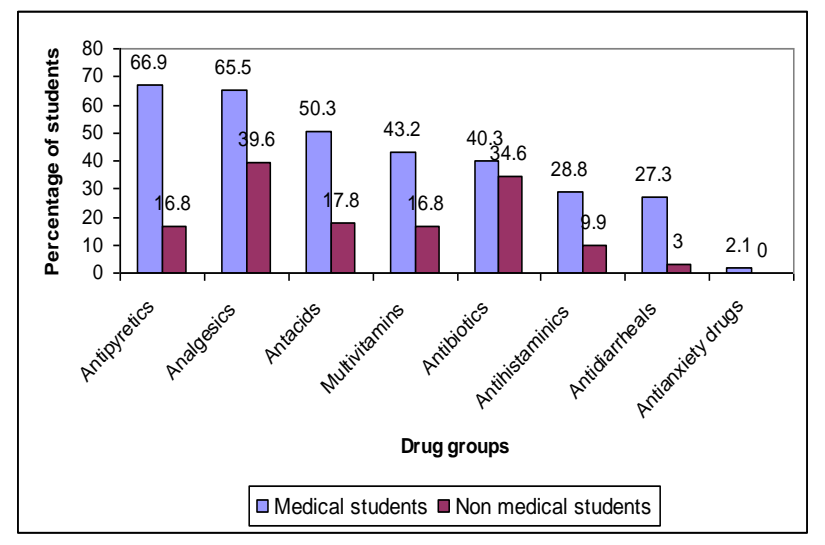

Figure 3: Common drug groups used for selfmedication.

\section{DISCUSSION}

Increase in availability of non-prescription drugs has led to rise in the practice of Self-medication and the present study further reiterates this fact. Majority of the respondents in our study had consumed non-prescription drugs and similar results have been observed in many studies. ${ }^{3,5-11}$ There was not much difference in percentage of students from medical or non-medical field consuming OTC drugs. Though the medical students have more access to knowledge about disease and its treatment and hence would be expected to self-medicate more but the rampant sale of non-prescription drugs and exposure to sources like print or electronic media have made even the non-medical students knowledgeable about them. ${ }^{10}$ The most common source of information about nonprescription drugs was pharmacology books among the medical students while it was previous doctor prescriptions available among the non-medical students. Various other studies have reported books, family \& friends and media as important sources of knowledge about self-medication. ${ }^{8,9}$ Majority of the medical students preferred brand drugs to generic ones while most of the non-medical students had no preference and took whatever was available. This maybe because of the fact that non-medical students don't have any knowledge about the form of these drugs. The preference of brand drugs among medical students may be because of the belief that generic drugs is less efficacious than brand drugs as advertisement \& promotion for sale of brand drugs is done more than their generic counterparts. ${ }^{8}$ The awareness about buying the drugs in proper dosage and completing the course of medication was present more in medical as compared to non-medical students. Similarly awareness about drug interactions among various drugs was more with medical students which can be attributed to pharmacology books and medical teaching which lays a lot of stress on these issues to prevent irrational drug use. The non-medical students lack this direct interaction with medical faculty and believe whatever the internet, friends or family member tells them. 
Most of the medical students felt that OTC drugs had minor ADRs like sedation, gastric upset, headache etc. which were tolerable and they hardly suffered from them while more of non-medical students thought they were not safe to use though majority had not experienced any side effect. Hence the knowledge that OTC drugs are not always safe for everyone was fairly well present among non-medical students too which can be again attributed to internet or drug inserts available. It was though good to know that majority of the students from both the groups knew that non-prescription drugs should never be given to pregnant women, children or elderly and a medical consultation should always be sought.

The preference for prescription drugs over nonprescription drugs was mentioned by majority of the respondents from both the groups which is nice to know. This is contrary to the expectation that medical students have better knowledge about the drugs and hence would prefer to self-medicate rather than taking a registered doctor's advice. The most common group of nonprescription drugs used by medical students were antipyretics \& analgesics like paracetamol, diclofenac sodium, aspirin etc. followed by antacids (ranitidine, omeprazole) while similar analgesics, antibiotics (amoxicillin, azithral, norfloxacin etc.) and antacids (omeprazole) were commonly used by non-medical students. All the above mentioned commonly used drugs are easily available over the counter leading to their increased consumption. The injudicious use of nonprescription drugs carry serious adverse effects and insufficient knowledge about them is dangerous. ${ }^{8}$ The use of antibiotics like azithromycin and amoxicillin was seen more among non-medical students which is a cause of concern as they lack proper medical knowledge and irrational use of antibiotics can lead to drug resistance which is becoming a grave health concern in India. Hence it is important to spread awareness among the general population as well as restrict the sale of these drugs without a proper prescription. The use of alternative medicines like ayurvedic or homeopathic drugs along with allopathic was seen more among non-medical students than medical students. This may be because of the fact the non-medical students have more positive attitude towards alternative medications which they feel could enhance the recovery process and they have less side effects while medical students rely mostly on allopathic drugs. A good percentage of medical and nonmedical students prescribe such drugs to family members, friends or a patient but it is not a good practice as these medical students yet are not registered practitioners and they lack the complete knowledge about drugs and diseases. It is not necessary that if a drug suits them it will benefit the other person too. Also the drug interactions, patient's drug history etc has all to be taken into account. Such practices by the non-medical students need to be completely discouraged because they have insufficient medical knowledge and the above said reasons.
Majority of the students felt that sale of non-prescription drugs should not be banned but they should come with a drug information leaflet. The reason could be easy access to them for common ailments like fever, cold, headache etc. for which the students were reluctant to visit a registered practitioner to save both time and money.

\section{CONCLUSION}

The present study reflects the magnitude of problem of Self-medication which is rampant not only among medical students but non-medical students too. Many studies in the past have highlighted similar issues. Proper education and dissipation of information about nonprescription drugs can lead to their responsible and controlled use which can treat minor illnesses. Also the health regulatory authorities should exercise strict control over the injudicious sale of these drugs without a proper prescription by the doctor which will further promote rational use of these drugs.

\section{ACKNOWLEDGEMENTS}

The authors would like to thank the medical and the nonmedical students for their participation in the study.

\section{Funding: No funding sources \\ Conflict of interest: None declared \\ Ethical approval: The study was approved by the Institutional Ethics Committee}

\section{REFERENCES}

1. Tripathi KD. Introduction, routes of administration. In: Tripathi KD. Essentials of Medical Pharmacology. $7^{\text {th }}$ Ed. New Delhi: Jaypee Brothers Medical Publishers (P) Ltd; 2013:1-9.

2. Gupta VK, Gupta CD, Patel JR. Assessment of awareness and attitudes towards over the counter (OTC) drugs amongst urban population: a questionnaire based study. Res J Pharm Biol Chem Sci. 2012;3(2):1037-41.

3. Ghosh A, Biswas S, Mondal K, Haldar M, Biswas S. A study on knowledge and practices of over the counter medications among $2^{\text {nd }}$ year medical students. WJPPS. 2015;4(7):1074-81.

4. Gutema GB, Gadisa DA, Kidanemariam ZA, Berhe DF, Berhe AH, Hadera MG, Hailu GS, Abrha NG, Yarlagadda R, Dagne AW. Self-medication practices among health sciences students: the case of Mekelle University. J App Pharm Sci. 2011;1(10):183-9.

5. Patel P, Prajapati A, Ganguly B, Gajjar B. Study on impact of pharmacology teaching on knowledge, attitude and practice on self-medication among medical students. Int J Med Sci Public Health. 2013;2(2):181-6.

6. Sontakke SD, Bajait CS, Pimpalkhute SA, Jaiswal KM, Jaiswal SR. Comparative study of evaluation of self-medication practices in first and third year 
medical students. Intl J Biol Med Res. 2011;2(2):561-4.

7. Bashir MSM, Bansod KA, Khade A, Konnoju M, Rani U, Vadala KK. Self-medication-a comparative study between $2^{\text {nd }}$ and $3^{\text {rd }}$ year medical students. Int J Basic Appl Med Sc. 2013;3(2):1-7.

8. Atray M, Kumar R. Self-medication pattern and its comparison amongst medical and non-medical college students of Udaipur, India. IJCRR. 2013;5(1):36-43.

9. Parakh R, Sharma N, Choudhary V, Parakh KK, Parakh R, Gour P. A comparative study of Selfmedication practice among medical and engineering students in a private university in North India. WJPPS. 2014;3(5):933-44.

10. Syed N, Naseer M, Memon MQ, Rani K. Prevalence of self-medication and its practice among the medical and non-medical students. JLUMHS. 2014;13(2):79-82.

11. Jagadeesh K, Chidananda KN, Revankar SP, Prasad NS. Study on Self-medication among $2^{\text {nd }}$ year medical students. Int $\mathbf{J}$ Basic Clin Pharmacol. 2015;4(1):164-7.

Cite this article as: Tikoo D, Gupta M, Sharma G. Comparison of awareness, attitude and use of nonprescription drugs among medical and non-medical undergraduates: A questionnaire based study. Int J Basic Clin Pharmacol 2016;5:243-50. 